\title{
木造床の鉛直振動特性に及ぼす人間荷重の影響に関する実験的研究（第 1 報） EXPERIMENTAL STUDY ON EFFECT OF HUMAN-LOAD ON VERTICAL DYNAMIC CHARACTERISTICS OF WOODEN FLOOR (PART 1)
}

\author{
鈴木秀三*, 藤野栄一**, 野口弘行*** \\ Shuzo SUZUKI, Eiichi FUJINO and Hiroyuki NOGUCHI
}

\begin{abstract}
Impact hammer tests were conducted to demonstrate the effect of human load on vertical vibrational characteristics (first natural frequency and damping factor) of wooden floors. The specimen was a $6.5 \mathrm{~m}$-long-span and $1.0 \mathrm{~m}$-wide wooden floor consisted of two $120 \mathrm{~mm}$ wide and $300 \mathrm{~mm}$ deep laminated wood timbers and $21 \mathrm{~mm}$-thick plywood sub-floor. The support and live load conditions of the specimen were changed. The live load combined with human load and furniture load ranged from 0 to $60 \mathrm{~kg} / \mathrm{m}^{2}$ respectively were applied to the wooden floor.

The test results indicate, i) Human load hardly affects the first natural frequency of the wooden floor, ii) The value of damping factor at first natural frequency increases in proportion to the rate of human load over the weight of a wooden floor, iii) The measured first natural frequencies of the wooden floors coincide with those calculated according to the vibration theory for bending continuous model with the bending stiffness and the weight (the sum of dead load and furniture load except the human load) of the wooden floor.
\end{abstract}

Keywords : Wooden floor, Vertical vbration, Dynamic charastatics, Human load, Furniture load 木造床，鉛直振動，振動特性，人間荷重，物品荷重

\section{1.はじめに}

、質構造における床の面外変形・振動については, 日本建策学会「木 質構造設計規準・同解説」1)の「5. 部材の設計 504 曲げ材」で規定 される「曲げ材の所要剛性」によるところが一般的である，平成 14 (2002) 年には同規準の改定が行われ，「通常の場合：梁の類」につい ては, 従前「初期変形における最大たわみがスパンの $1 / 300$ 以下,かつ, $2 \mathrm{~cm}$ 以下」であったものが，「初期変形における最大たわみがスパン の 1/300 以下，かつ，振動障害がないこと」と改められた.

従前の「最大たわみ量 $2 \mathrm{~cm}$ 以下」の根拠は，木質構造設計規準の 解説によれば, 昭和 19(1944) 年に発表された竹山・久田の研究 ${ }^{2)} に$ 基づくもので, その誘導は次の仮定に基づいたとされている.

(1)床梁の固有振動数は曲げ振動理論に基づくものとし，床梁を単純 梁とみなす.

(2)梁の最低の振動数を $10 \mathrm{~Hz}$ 程度とする.

(3)林板・根太の影響や仕口拘束などによる振動数の増大を見込む（増 大率を $\alpha$ と定義).

(4)木上に人が多勢のっている場合の振動は減衰してかえって感じな くなるので，荷重 w の中から人間荷重を除外する（通常用いる床の
設計荷重と固定ならびに物品荷重の和との比を $\beta$ と定義).

(5)所要の振動数 $n_{e}$ を, 事務所・教室については $n_{e}=9 \sim 10 \mathrm{~Hz}$, 倉 庫については $n_{e}=5 \mathrm{~Hz}$ 程度とする.この場合， $\alpha$ は 1.2 程度， $\beta$ は 荷重の性質を勘案して用途別に定める.

(6)曲げ振動理論に基づく梁の振動周期式中の EI 之静的等分布積載時 のたわみ式の EI とを関連づけて, 事務所・教室・倉庫それぞれの場 合についてたわみ限度を誘導し，得られた 3 式を大観して， $\delta \leqq 2 \mathrm{~cm}$ を誘導する.

以上のように，旧規準の「最大たわみ量 $2 \mathrm{~cm}$ 以下」は，事務所・ 教室・倉庫など比較的大規模な木造建築物でスパンが $6 \mathrm{~m}$ を超える 梁の振動障害を防ぐための一つの目安として定められたものであっ たといえよう：これに関連して, 住宅の居室の最大たわみ量について, 飯塚は $\alpha ， \beta$ をそれぞれ $1.5,0.8$ とおいて $\delta \leqq 0.65 \mathrm{~cm}$ を誘導し， 住宅の床梁について「最大たわみ量 $0.7 \mathrm{~cm}$ 以下」で設計することを 提案している ${ }^{3)}$.

上述の木造梁の振動障害対策に関する規定は簡便である反面，規 定值の誘導根拠となる与条件が固定化されており，建物の用途・要 求性能・構法変化に柔軟に対応できず，したがって，設計者が要求
* 職業能力開発絵合大学校建築工学科 教授・工博

** 職業能力開発総合大学校東京校建築科 講師 ·修士 (工学)

**** 明治大学理工学部建築学科 教授・ 工博
Prof., Dept. of Architectural Engineering, The Polytechnic University, Dr. Eng. Lecturer, Dept. of Architecture, Tokyo Institute Polytechnic University, M. Eng. Prof., Dept. of Architecture School of Science \& Technology, Meiji Univ., Dr. Eng. 
性能を勘案して振動特性值を決定することには適していない．また， 集成材・単板積層材 (LVL), 合板・構造用パネル，木質複合 I 型梁な どを始めとするエンジニアリング・ウッド (Engineering Wood) の 出現により，木質構造による大スパン大規模建築が可能になってい る.さらには，木材の使用促進が二酸化炭素の削减，地球温暖化防 止に貢献できることと相俟って，従来のような住宅を代表とする低 層小規模建築物だけでなく，住宅以外の用途をもつ中層建築物実現 の可能性を探る動きも出てきており，このような比較的スパンが大 きな木造床については経験が少ないことも相俟って振動障害の発生 が懸念される状況となってきている.

一方, 建築物の居住性能評価の観点から，日本建築学会「建築物 の振動に関する居住性能評価指針·同解説（1991 年)」4）が制定され， 建築物床の対鉛直振動性能は, 床の応答波形加求められる振動数 振動振幅・减衰定数に基づき評価されることになっていた。この指 針に関しては，一般的な木造床仕様では「ランク外」と評価される こと 5）もあり，木造床の高堿衰性能を視野に入れた評価軸の提案 5)， 比較的軽量な床を対象とした床振動の測定・評価法に関する提案 ${ }^{6)}$ もなされてきていた．同指針は 2004 年 5 月に改定され7)，床応答波 形の $1 / 3$ オクターブバンド分析結果を応答加速度, 振動数および人 の振動知覚確率により定められた性能評価曲線と照合して評価する 方法が採用されたが，このことにより床応答波形データの蓄積ある いは床応答波形予測手法の必要性がますます高まったといえよう.

しかしながら, 木質構造においては構造設計に必要な諸情報が整 備されておらず，固有振動数予測手法すら確立されていないのが現 状である。

このような背景から，筆者らは，旧木質構造設計規準の規定の妥 当性を検証した上で, 現行木質構造設計規淮の目指す要求性能に応 じた部材設計法を検討するための基碟データを得るために，実大木 造部分床を対象とした実験的研究を実施してきていたが ${ }^{8,9)}$ ，木造床 の鉛直振動特性に及ぼす人間荷重の影響について有用な知見を得た ので,ここに報告するものである. 本報では，木造床の鉛直振動に 対する 1 次固有振動数および减衰定数に及ぼす人間荷重の影響, 並 びに， 1 次固有振動数の推定に用いる連続体の曲げ振動理論の適用 性について述べ，次報では木造床における人閒荷重の忘答に関する 実験結果について述べる.

\section{2. 試験体}

一般的な木造床組の構成方法には単床（根太床）, 複床 (梁床), 組床があるが，これらを木質構造の構造設計手法の観点からみれば、 全てが「梁の類」によって支えられる形式であると言える. 木質構 造においては, 床の最小構成単位を 1 方向に鉛直荷重を伝達する「梁 の類」とそれに連結・結合された部材類で構成されると仮定し，床 組全体はこの最小構成単位が並列配置された状態として取り扱うこ とが通例である．また、床を構成する部材の設計においては，積載 荷重が等分布荷重として作用すると仮定することが一般的である. このような背景にしたがい, 実験に用いる実大部分床の構成及び載 荷条件は，木質構造の複床（梁床）の構造設計において通常仮定さ れる状態を具現化することを念頭に置いたものとしている.

\section{(1) 試験体の概要}

試験体は，Fig. 1 に示すような床下地，根太および 2 本の梁で構成

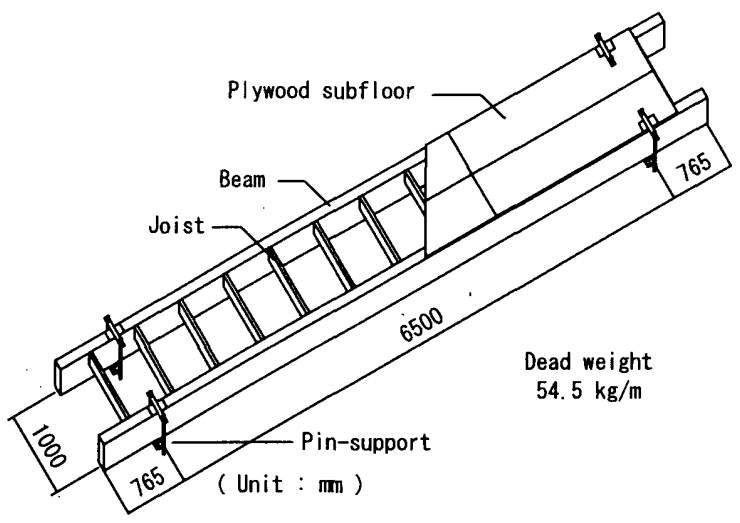

Fig. 1 Schematic diagram of wooden floor (Type-A)

Table 1 Specification of members of wooden floors

\begin{tabular}{|c|c|}
\hline Member & Specification \\
\hline \multirow{2}{*}{ Beam } & Glued laminated timber(E120-F375,JAS: Douglas Fir) \\
\hline & Size $: 120 \mathrm{~mm} \times 300 \mathrm{~mm}$, Length $: 8030 \mathrm{~mm}$, Specific gravity: 0.53 \\
\hline \multirow{2}{*}{ Joist } & Dimension lumber 206 (SI, $38 \times 140$ ), Specific gravity: 0.54 \\
\hline & Metal hanger: $\mathrm{JH} 206(6-\mathrm{ZN} 40$ to $\mathrm{Beam})$ \\
\hline & ss: $21 \mathrm{~mm}(600 \times 2400,7 \mathrm{ply}, T \& G)$ \\
\hline
\end{tabular}
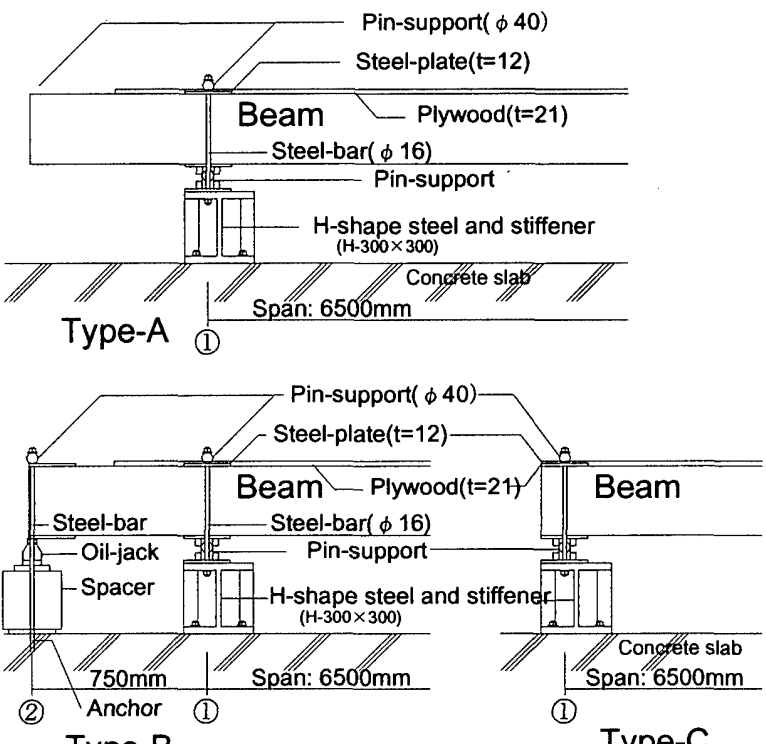

Type-B

Type-C

Fig. 2 Details of beam-ends and supports

される幅 $1.0 \mathrm{~m}$, スパン $6.5 \mathrm{~m}$ の実大部分床で, 床下地である構造用合 板を梁・根太に釘打ち張りしたものである. 床の構成部材は Table 1 に示す通りであるが, 実験は次項で述べる試験体種類 Type-A $\rightarrow$ Type-B $\rightarrow$ Type-C の順に条件を変えて行うこととしたので, 部材は 全試験種類を通して同一のものである. 梁の断面は, 室の用途を事 務室・店舗の売り場・集会室等とした場合の設計条件を勘案して, 長期荷重（固定荷重十積載荷重） $5500 \mathrm{~N} / \mathrm{m}^{2}$ が作用した場合のスパン 中央部のたわみ量がスパンの $1 / 300(6500 / 300=21.7 \mathrm{~mm})$ 以下となるこ とを目途に決定している，なお，梁のたわみ計算に用いたヤング倸

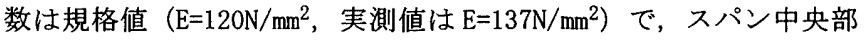
の変形量は約 $19 \mathrm{~mm}$ と計算された.

（2）試験体の支持条件

試験体の種類は, 形式と支持条件の違いにより, Type-A, Type-B, Type-Cの 3 種類に分類される. 各試験体タイプともに、床梁はコン 
クリートスラブに固定された $\mathrm{H}$ 形鋼上にピン支持の治具を介して支 持したが (Fig. 2 参照)，この措置は床組上下方向周りの構成の影響 を排除し床自身の振動性状についてだけ注目するためである.

試験体種類毎の特徴とねら以は次の通りである.

Type-A：長さ $8.0 \mathrm{~m}$ （実長 $8.03 \mathrm{~m}$ ）の床の端部を両側に約 $0.75 \mathrm{~m}$ （実 長 $0.765 \mathrm{~m}$ ）づつ跳衫出した形の床の両端が自由な状態にある支持ス パン $6.5 \mathrm{~m}$ の床である。床組は支持点位置の上下に設置したピン治具 を介して引き寄せボルトにより H形鋼に緊結されている．この試験 体の自由な状態にある両端部を拘束した状態が Type-Bである.

Type-B：Type-A の跳ね出し部分先端位置についてもピン治具により 拘束したもので，床組が連続梁的に構成された状態についての振動 特性を調べるための試験体である，なお，実験は積載荷重が無載荷 の場合と人間重量 $30 \mathrm{~kg} / \mathrm{m}^{2}$ の場合についてだけ行っている.

Type-C：Type-A の跳好出し部分を切り落とした形の床組で，通常の 構造計算で仮定される単純支持された支持スパン $6.5 \mathrm{~m}$ の床に相当す る形としたものである.

（3）積載荷重の条件

木造床を設計する場合の積載荷重は、建築基準法施行令によるこ とが一般的である，建築基隻法施行令の数值の由来は詳らかではな いが，日本建築学会建築物荷重規準案・同解説（1975 制定）10）に よれば, 積載荷重は人間荷重と物品荷重に分類され, 設計用積載荷 重は人間並びに家具の平均重量に室用途に态じた集中係数・衝撃係 数を乗じて決定するとしており，その值は建築基準法施行令の值と 基本的に同じである.このことを踏まえ，同規淮 ${ }^{10)}$ 所載の人間及 び家具の平均重量（集中係数・衝撃係数考慮前の值：人間 $30 \sim 180$ $\mathrm{kg} / \mathrm{m}^{2}$, 家具 $30 \sim 70 \mathrm{~kg} / \mathrm{m}^{2}$ ) と両重量の室用途別平均重量の合計（事 務室 $60 \mathrm{~kg} / \mathrm{m}^{2}$, 居室 $65 \mathrm{~kg} / \mathrm{m}^{2}$, 教室 $110 \mathrm{~kg} / \mathrm{m}^{2}$, 商店 $\left.135 \mathrm{~kg} / \mathrm{m}^{2}\right)$ を 参考として，実験における載荷荷重について両荷重の組合せを 0 〜 $120 \mathrm{~kg} / \mathrm{m}^{2}$ の範囲で変化させて実験を行うこととした．具体的には、 人間および物品重量をそれぞれ $0,30,60 \mathrm{~kg} / \mathrm{m}^{2}$ とし, Table 2 に示 す重量の組合せで実験を行うこととした.

人間荷重の載荷方法は，運動靴を履いた人間が所定重量になるよ うにダミーウェイトを背負った状態（リュックサックを使用）で支 持スパン内の床面上に立つこととし, 荷重条件に応じて人間 $3 \sim 6$ 人を分布荷重の状態に近くなるように配置することとした．これは， 人間の姿勢が床の減衰性に及ぼす影響について，竹山ら ${ }^{2)} か ゙ 10$ 種類 の異なる人間の姿勢について実験を行った結果として [ 直立 $] ，[$ 尻 つけ ], [椅子掛け ]，[横臥 ] 等の場合に床振動の减衰が非常に早 いこと，[弾み立ち] の場合には振動はやや継続すること指摘して

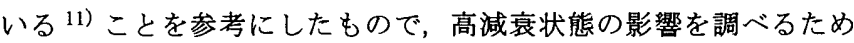
と実験実施の簡便性を考慮した結果である。一方，物品荷重として は鋼製の鍾（約 $25 \mathrm{~kg}$ / 個）を用い，荷重条件に忘じて $8 \sim 16$ 個を 支持スパン内の床組上に配置している.Fig. 3 には, 人間荷重 60 $\mathrm{kg} / \mathrm{m}^{2}(60 \mathrm{~kg} / \mathrm{m})$ ・物品荷重 $30 \mathrm{~kg} / \mathrm{m}^{2}(30 \mathrm{~kg} / \mathrm{m})$ とした場合 (H60-F30) の状況が模式図として示してあるが，等分布荷重とした理由につい ては本節の頭書に記した通りである。

（4）床の自重と曲げ㴊性

Table 3 には, 静的加力実験 [H形銅を銛 $(362 \mathrm{~kg})$ として用いた スパン中央 1 線集中載加実験およびスパン 3 等分点 2 線集中載加実 験]における，スパン中央部の変位に基づいて計算される床組の曲
Table 2 Name of live-load condition (combination of human-load and furniture-load)

\begin{tabular}{|l|c|c|c|c|}
\hline \multicolumn{2}{|c|}{ Live-load } & \multicolumn{3}{c|}{ Funiture-load $: \mathrm{N} / \mathrm{m}^{2}\left(\mathrm{~kg} / \mathrm{m}^{2}\right)$} \\
\cline { 3 - 5 } & $0(0)$ & $294(30)$ & $588(60)$ \\
\hline \multirow{2}{*}{$\begin{array}{l}\text { Human-load : } \\
\mathrm{N} / \mathrm{m}^{2}\left(\mathrm{~kg} / \mathrm{m}^{2}\right)\end{array}$} & $0(0)$ & $\mathrm{H} 0-\mathrm{F0}$ & $\mathrm{HO}-\mathrm{F} 30$ & $\mathrm{HO}-\mathrm{F} 60$ \\
\cline { 2 - 5 } & $294(30)$ & $\mathrm{H} 30-\mathrm{FO}$ & $\mathrm{H} 30-\mathrm{F} 30$ & $\mathrm{H} 30-\mathrm{F} 60$ \\
\cline { 2 - 5 } & $588(60)$ & $\mathrm{H} 60-\mathrm{FO}$ & $\mathrm{H} 60-\mathrm{F} 30$ & $\mathrm{H} 60-\mathrm{F} 60$ \\
\hline
\end{tabular}
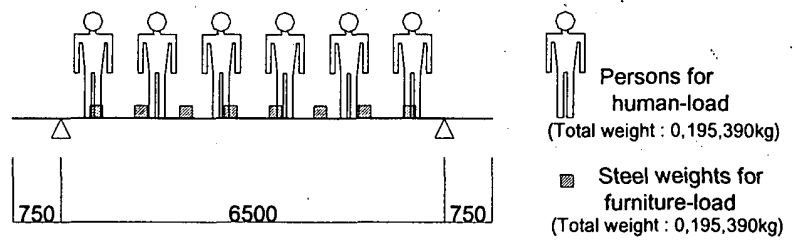

Fig. 3 Schematic diagram of live-load at H60-F30 for Type-A

Table 3 Bending stiffness of wooden floors

\begin{tabular}{|l|c|c|}
\hline \multirow{2}{*}{$\begin{array}{l}\text { Load } \\
\text { Condition }\end{array}$} & \multicolumn{2}{|c|}{ Bending-stiffness : El (kN-m) } \\
\cline { 2 - 3 } & with sub-floor & without sub-floor \\
\hline Mid-span loading & 9462 & 7247 \\
\hline 2-point loading & 9297 & 7500 \\
\hline Average & 9380 & 7374 \\
\hline
\end{tabular}

げ剛性（EI）が示してある．同表より，合板を釘打ち張りした床組の 曲げ剛性の值は $9380 \mathrm{kN} \cdot \mathrm{m}^{2}$ (両実験で得られた值の平均值) で，合 板を釘打ち張りすることにより曲げ剛性が約 $25 \%$ 増大することがわ かる，なお，床の単位長さ当りの自重（固定荷重）は，床組構成後 の計量値に基づいて計算すると $54.5 \mathrm{~kg} / \mathrm{m}$ であった.

\section{3. 試験方法}

床組の固有振動数および堿衰定数を評価するための動的試験法を 決定するに際し，予備実験として加振器を用いた強制加振実験とイ ンパクトハンマー加振による自由振動実験を行い， 1 次固有振動数 および減衰定数について両者の結果に大きな差異がないことを確認 した上で，実験実施の簡便性を考慮して，インパクトハンマー加振 による自由掁動実験を採用した。

加振に用いたインパクトハンマーは加振部先端にゴム製チップを 取付けた重さが約 $1 \mathrm{~kg}$ のもので, 加振力はインパクトハンマー内蔵 の圧電型ロードセルにより計測され, その加振力は, 全試験を通して, 作用時間は約 0.02 秒間, 最大加振力は $500 \sim 1000 \mathrm{~N}$ であった. なお， 床組の加振位置には厚さ $40 \mathrm{~mm}$ のスポンジゴムを取付け, 低い周波数 帯域に加振力を集中させる処置をとっている.

床組の応答加速度は，床組を構成する 2 本の梁のスパン中央部 および 3 等分点位置（合計 6 点）について，サーボ型加速度計（容 量：2G）を用いて測定した．また，各梁のスパン中央部位置の応答 変位については，接触式の変位計（容量は $5 \mathrm{~mm}$ または $10 \mathrm{~mm}$, 精度は $1 / 2000 \mathrm{~mm}$ または $1 / 1000 \mathrm{~mm}$ ）を用いて測定した. データ収録には多チャ ンネル信号処理装置を用い，インパクトハンマーの加振力と床組の 応答加速度および応答変位の電圧信号 (約 $0.1 \mathrm{~Hz}$ で $\mathrm{AC}$ カップリング, 約 $250 \mathrm{~Hz}$ でアンチェリアジングフィルタを適用）に対してA/D.変換 を行っている．サンプリング周波数は時刻歷応答波形の測定につい て $1024 \mathrm{~Hz}$ ，周波数応答関数については $512 \mathrm{~Hz}$ ，測定時間は 8 秒間を 基本と.している，なお，周波数応答関数は，測定周波数範囲を 0 〜 $256 \mathrm{~Hz}$ とし, 各試験条件毎にインパクトハンマー加振 3 回のデータに ついて平均化処理を施している. 


\section{4. 実験結果とその考察}

Fig. 4 には，試験体 Type-Aについての，インパクトハンマー加振 による自由振動に対する梁中央部の時刻歷変位応答波形が例示して ある. Fig. 5 には，同じく試験体 Type-Aについての，インパクトハ ンマーの加振力で規準化したスパン中央部加速度応答と振動数の関 係，いわゆる周波数応答関数が例示してある.Fig. 5(a)〜 (c) は, 人間荷重がそれぞれ $0,30,60 \mathrm{~kg} / \mathrm{m}^{2}$ の場合において物品荷重が 0 〜 $60 \mathrm{~kg} / \mathrm{m}^{2}$ に変化した状態を, Fig. 5(d)〜（f）は，物品荷重がそ れぞれ $0,30,60 \mathrm{~kg} / \mathrm{m}^{2}$ の場合において人閒荷重が $0 \sim 60 \mathrm{~kg} / \mathrm{m}^{2}$ に変化した状態を, それぞれ示してある. Fig. 5 中のデータは重複表
示されているが，各グラフの縦軸の大きさが異なるため，一見別デー タに見えることに注意されたい!

Table 4 には, Fig. 4 に例示したような変位応答波形（時刻歴）の 初期 $2 \sim 4$ 周期分の記録に基づき，日本建築学会「建築構造物の振 動実験」12)の「2.4.2 自由振動波形の解析」に示される全振幅によ る算定手法にしたがって求めた卓越振動数および減衰定数の值と, Fig. 5 に例示した周波数応答関数のピークを 1 次固有振動数とし，そ の 1 次固有振動数のピークに対していわゆる1/ 22 法を用いて算 出した減衰定数が，全試験体種類について一括表示してある，なお， 同表中に示す 1 次固有振動数㧍よび堿衰定数の值は，床を構成する
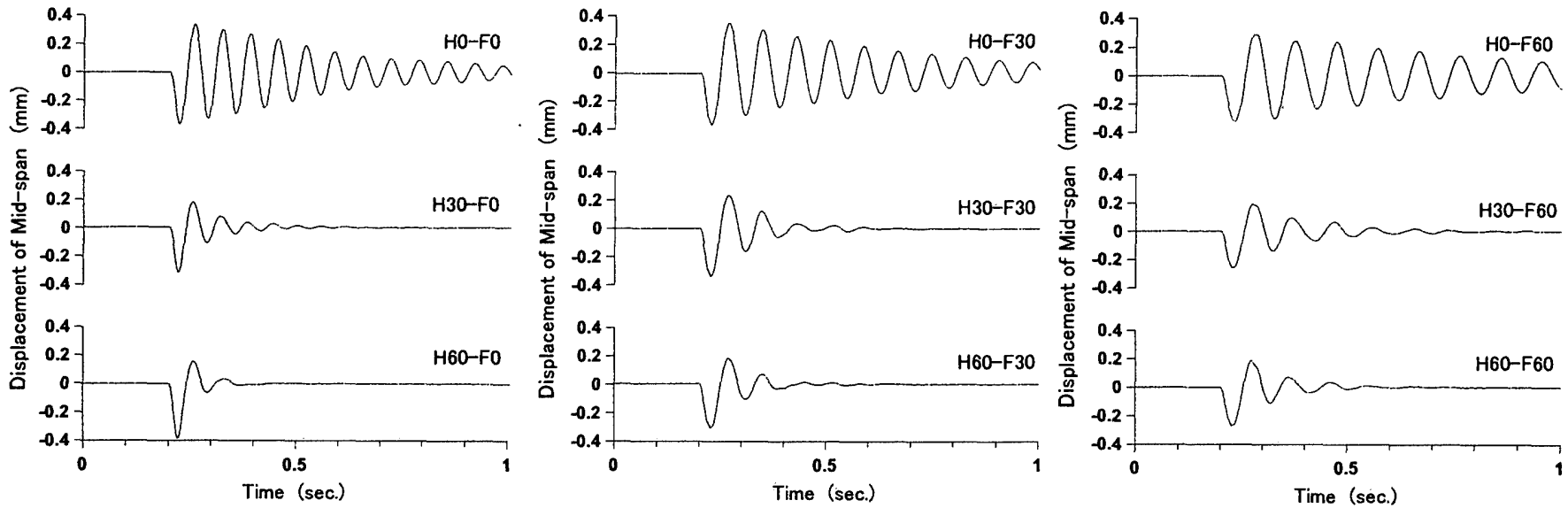

Fig. 4 Time record on mid-span displacement for type-A

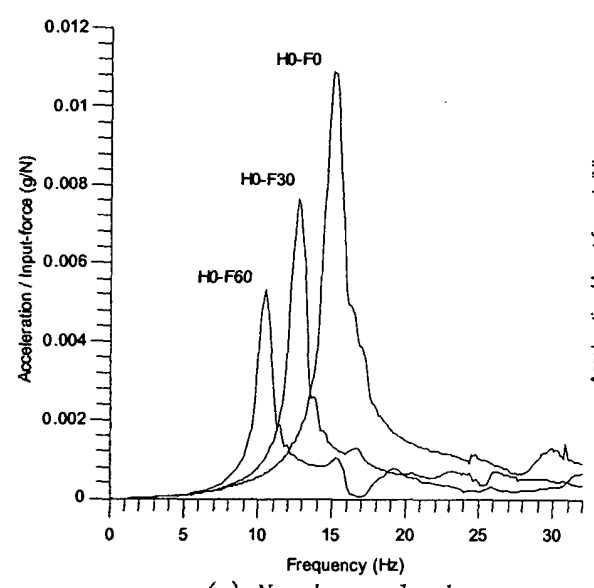

(a) Non-human-load

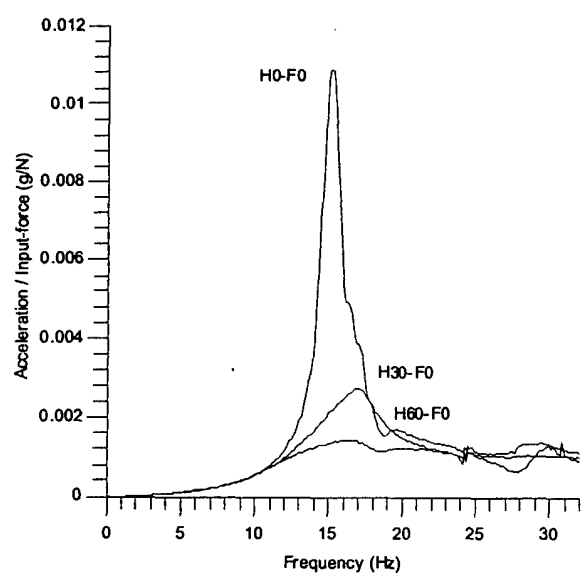

(d) Non-furniture-load

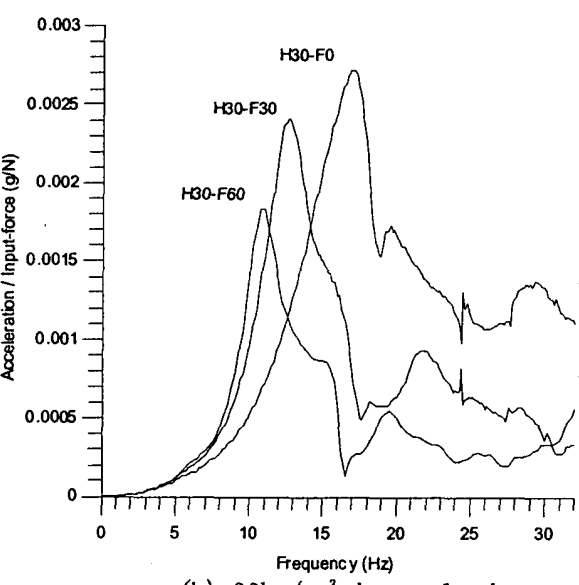

(b) $30 \mathrm{~kg} / \mathrm{m}^{2}$-human-load

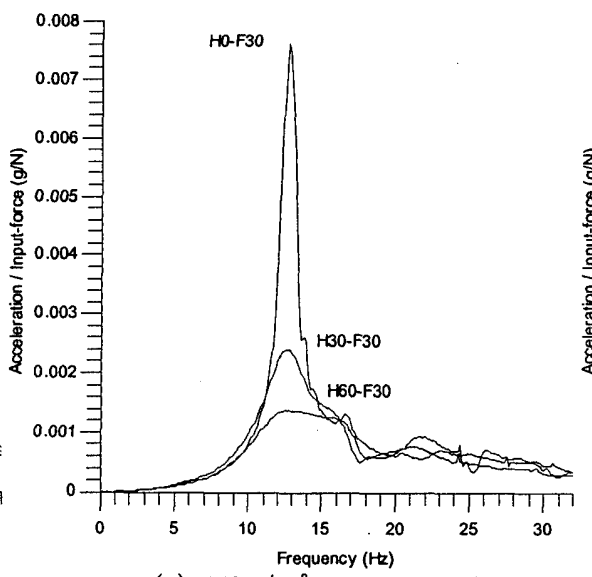

(e) $30 \mathrm{~kg} / \mathrm{m}^{2}$-furniture-load

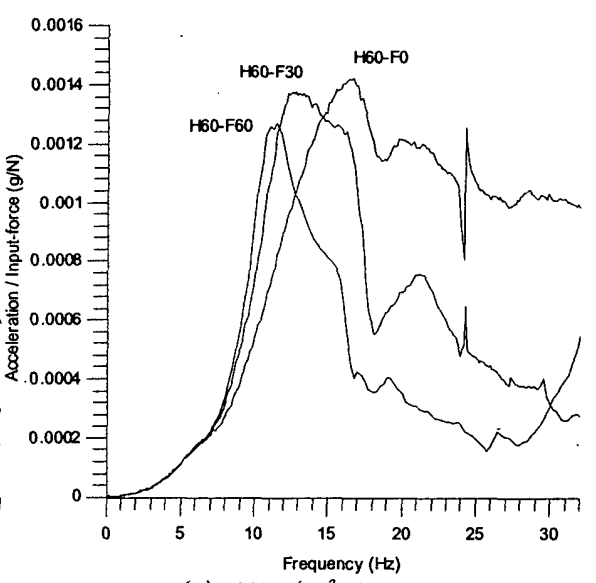

(c) $60 \mathrm{~kg} / \mathrm{m}^{3}$-human-load

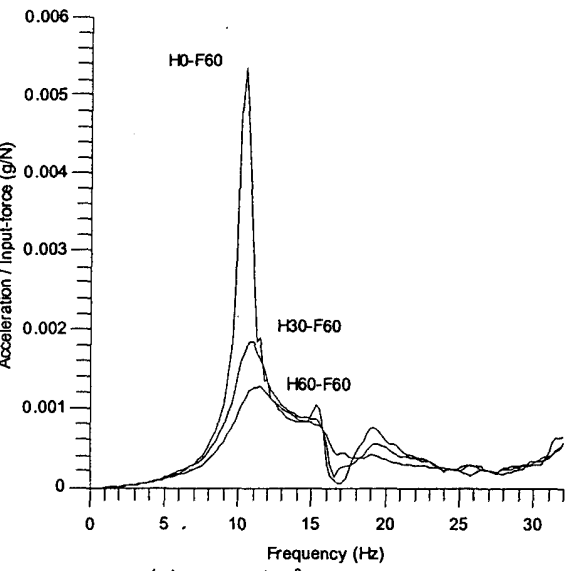

(f) $60 \mathrm{~kg} / \mathrm{m}^{2}-$ furniture-load

Fig. 5 Frequency response functions for Type-A 
Table 4 Results of vertical vibration tests (1st natural frequency and damping factor)

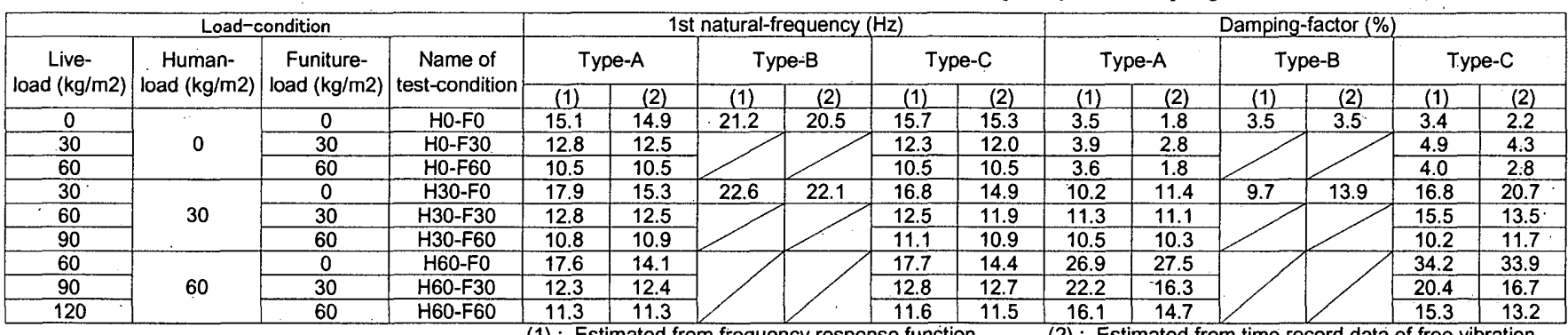

(1): Estimated from frequency response function

(2): Estimated from time record data of free vibration
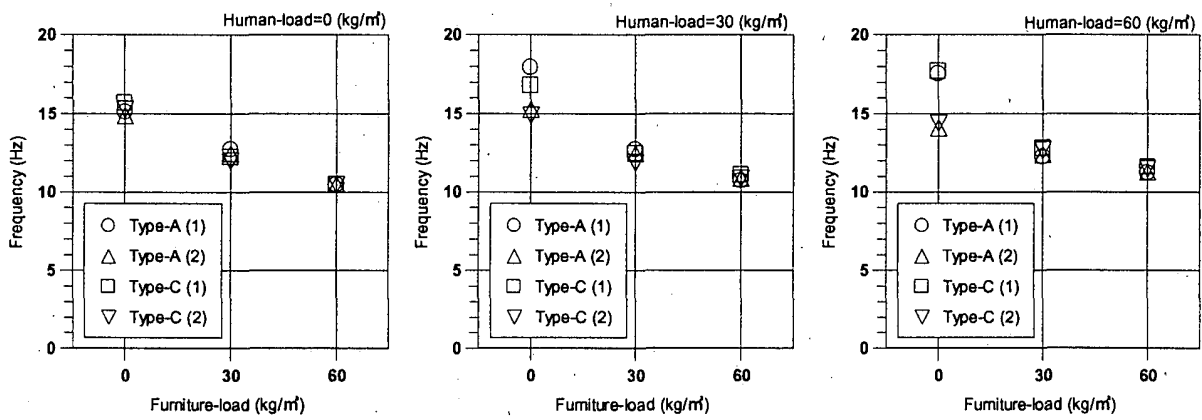

(a) Relation between frequency and furniture-load
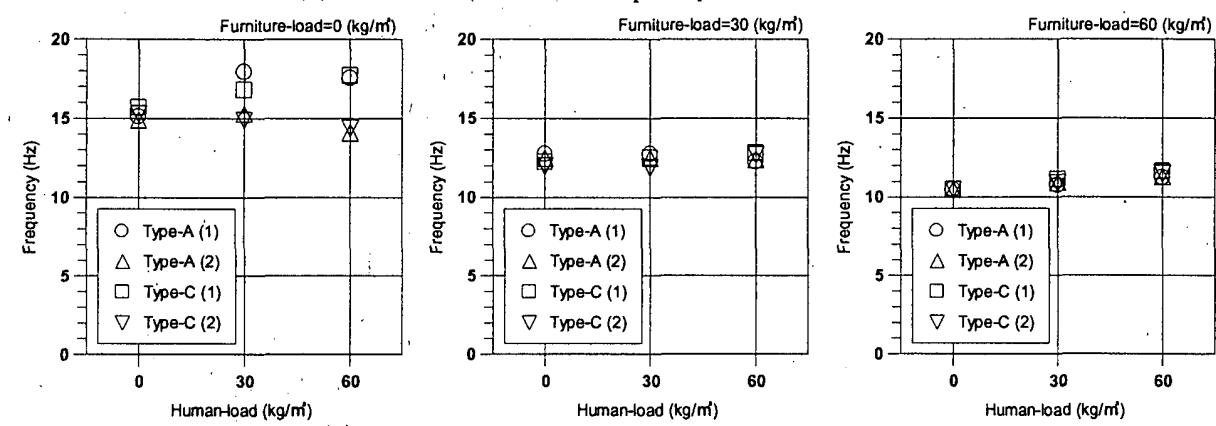

(b) Relation between frequency and human-load

Fig. 6 Relation among first natural frequency, furniture-load and human-load
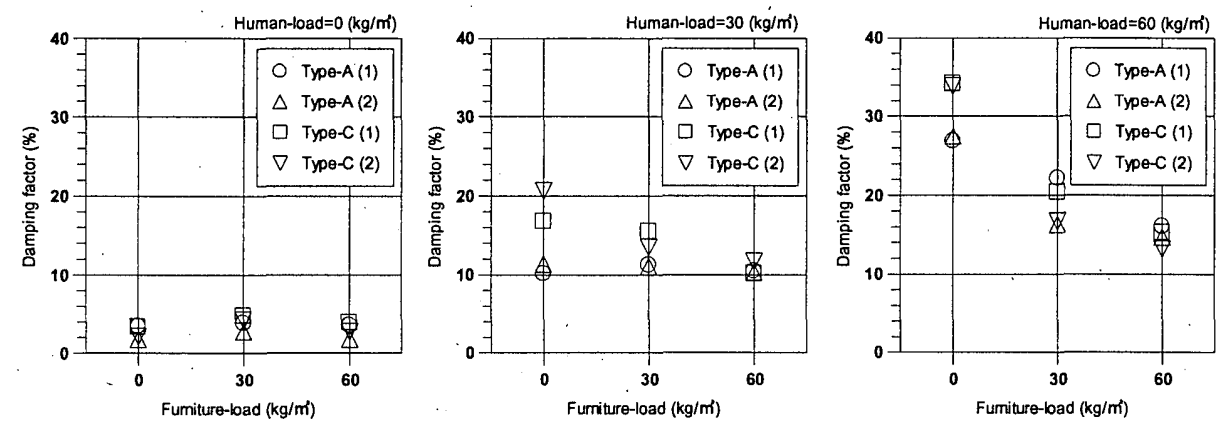

(a) Relation between damping factor and furniture-load
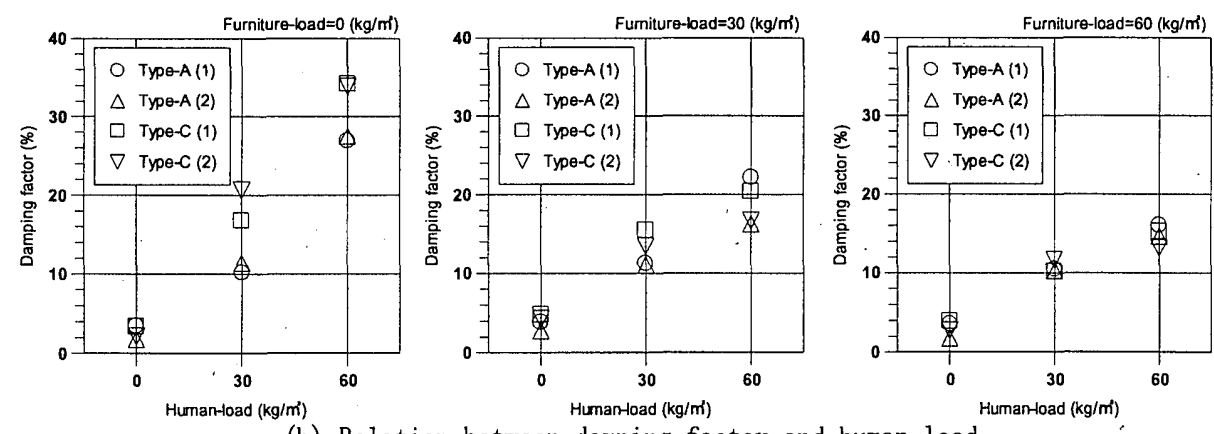

(b) Relation between damping factor and human-load

Fig. 7 Relation among damping factor, furniture-load and human-load
2 本の梁それぞれについて得られた值の平 均值である. また, 周波数応答関数に基づ いて 1 次固有振動数を決定するに当たって は, 実験モード解析により， 1 次固有振動 数に対忍する振動モード形が梁の曲げ振動 の 1 次モードである $\sin$ 関数波形の半周期 の形状と類似していることを確認している ことを付記しておく.

以上の実験結果に基づき，考察を進める.

\subsection{1 次固有振動数と積載荷重の関係}

Fig. 6 には, Table 4 に示した結果に基づ き, Type-A およびType-Cの場合の 1 次固 有振動数と物品荷重および人間荷重との関 係が示してある.Fig. 6(a) は, 人間荷重が それぞれ $0,30,60 \mathrm{~kg} / \mathrm{m}^{2}$ の場合において 物品荷重が $0 \sim 60 \mathrm{~kg} / \mathrm{m}^{2}$ に変化した状態 を, Fig. 6(b) は, 物品荷重がそれぞれ0, $30,60 \mathrm{~kg} / \mathrm{m}^{2}$ の場合において人間荷重が， 0 〜 $60 \mathrm{~kg} / \mathrm{m}^{2}$ に変化した状態を, それぞれ 示している. Fig.6から次のことがいえよ ว.

Type-A と Type-Cにおける物品荷重が 0 で人間荷重が $30 \mathrm{~kg} / \mathrm{m}^{2}$ [H30-F0］および 60 $\mathrm{kg} / \mathrm{m}^{2}$ [H60-F0] の場合の 1 次固有振動数 の値は、変位応答波形に基づく場合と周波 数応答関数に基づく場合とで約 $20 \%$ 異なる が、それ以外の場合には両同定法の違いに よる差は $5 \%$ 以下で両同定法による差異は 小さいことがわかる．評価值に大きな差異 が生じた Type-A の応答変位波形を眺めると [Fig. 4 参照]，[H60-F0］の場合は概ね 3 周 期で振動が収束し，振幅が概ね 0 に収束す， るまでの時間は約 0.4 秒間と短く, [H30-F0] の場合にあっても概ね 5 周期で振動が収束 していることがわかる.この傾问は試験体 Type-Cにおいても同様にみられたが，この ことは高减衰振動性を有する木造床の振動 特性值同定の困難性を示すものであろう.

木造床の 1 次固有振動数に及ぼす物品荷 重・人間荷重の影響を見るために, Fig. 6 
全体を眺めると，人間荷重が $0,30,60 \mathrm{~kg} / \mathrm{m}^{2}$ それぞれの場合にお いては物品荷重が 0 から $60 \mathrm{~kg} / \mathrm{m}^{2}$ に増加するに伴い， 1 次固有振動 数が低下する傾向がみられるのに対し [Fig.6(a) 参照], 物品荷重 が $0,30,60 \mathrm{~kg} / \mathrm{m}^{2}$ それぞれの場合においては人間荷重が 0 から 60 $\mathrm{kg} / \mathrm{m}^{2}$ に增加しても 1 次固有振動数はほとんど変化しない傾向がみら れる [Fig. 6(b) 参照].このことは, 物品荷重は床組の 1 次固有振動 数を低下させる因子となるが，本実験の固有振動数の範囲 $10 \sim 18 \mathrm{~Hz}$ では人間荷重の固有振動数への影響は小さく，床組の 1 次固有振動 数を推定する上ではその重量を除外して考えてよいことを示唆して いる. すなわち, 学会規淮において床の固有振動数 $10 \mathrm{~Hz}$ を目安と して「絶対変形量 $2 \mathrm{~cm}$ を誘導する際に, 『床上に人が多勢のってい る場合の振動は減衰してかえって感じなくなる』ことを理由として 『荷重 w の中から人間荷重を除外する』措置を採ったことは, 実態と して人間荷重は固有振動数に影響しないことから, 妥当な措置であっ たといえよう.

\subsection{1 次固有振動数に対する减衰定数と積載荷重の関係}

Fig. 7 には, Table 4 に示した結果に基づき,Type-A および Type-Cの場合の減衰定数と物品荷重および人間荷重との関係が示し てある.Fig.7(a) は，人間荷重がそれぞれ $0,30,60 \mathrm{~kg} / \mathrm{m}^{2}$ の場合 において物品荷重が $0 〜 60 \mathrm{~kg} / \mathrm{m}^{2}$ に変化した状態を, Fig. 7(b) は, 物品荷重がそれぞれ $0,30,60 \mathrm{~kg} / \mathrm{m}^{2}$ の場合において人間荷重が 0 〜 $60 \mathrm{~kg} / \mathrm{m}^{2}$ に変化した状態を, それぞれ示している. Fig. 7 から次 のことがいえよう.

Type-A における「H60-F30」およびType-Cにおける [H30-F0］と 「H60-F30」の減衰定数の值は、変位応答波形に基づく場合と周波数 応答関数に基づく場合とでは堿衰定数値として $5 \%$ 程度の差異があ るが、この理由も, 前述した高减衰振動性を有する木造床の振動特 性值同定の困難性によるものであると考えられる．この3例を除け ば，両同定法による評価値に大きな差異はみられないといってよか ろう.

木造床の减衰定数に及ぼす物品荷重・人間荷重の影響の全体的な 傾向を見るために, Fig. 7 を眺めると, 次のことが指摘できよう.

(1). 物品荷重が $0 \sim 60 \mathrm{~kg} / \mathrm{m}^{2}$ で変化した場合 [Fig. 7(a) 参照]： 人間荷重がない場合, 物品荷重が変化しても減衰定数に大きな変化 はなく $2 \sim 4 \%$ 程度である. 人間荷重が $30 \mathrm{~kg} / \mathrm{m}^{2}$ の場合, Type-A に ついては物品荷重が変化しても減衰定数に大きな変化はなく約 $10 \%$ 程度であるが, Type-Cについては物品荷重が増加するに伴い $18 \%$ 程 度から約 $10 \%$ に低下寸る傾向が見られる. 人間荷重が $60 \mathrm{~kg} / \mathrm{m}^{2}$ の 場合, 試験体タイプに拘わらず，物品荷重が増加するに伴い $30 \%$ 前 後から $15 \%$ に低下する傾向が見られる.

(2). 人間荷重が $0 \sim 60 \mathrm{~kg} / \mathrm{m}^{2}$ で変化した場合 [Fig. 7(b) 参照] :

物品荷重がない場合, 人間荷重が 0 から $60 \mathrm{~kg} / \mathrm{m}^{2}$ に変化すると減 衰定数は $4 \%$ 程度から約 $30 \%$ に飛躍的に增大することがわかる. 物 品荷重が $30 \mathrm{~kg} / \mathrm{m}^{2}$ および $60 \mathrm{~kg} / \mathrm{m}^{2}$ の場合にも人間荷重が増大するに 伴って減衰定数は大きくなる傾向があるが, 物品荷重が大きいほど その増加割合は小さい, Fig. 8 には Table 4 に示した結果に基づいた 减衰定数と [人間荷重／(固定荷重＋物品荷重)］値の関係が示して ある. 同図より，両者の間には概わ比例の関係があること，すなわち， 床の减衰定数の値は, 床の重量に対する人間荷重の割合に比例して 増加する傾向があることがわかる。

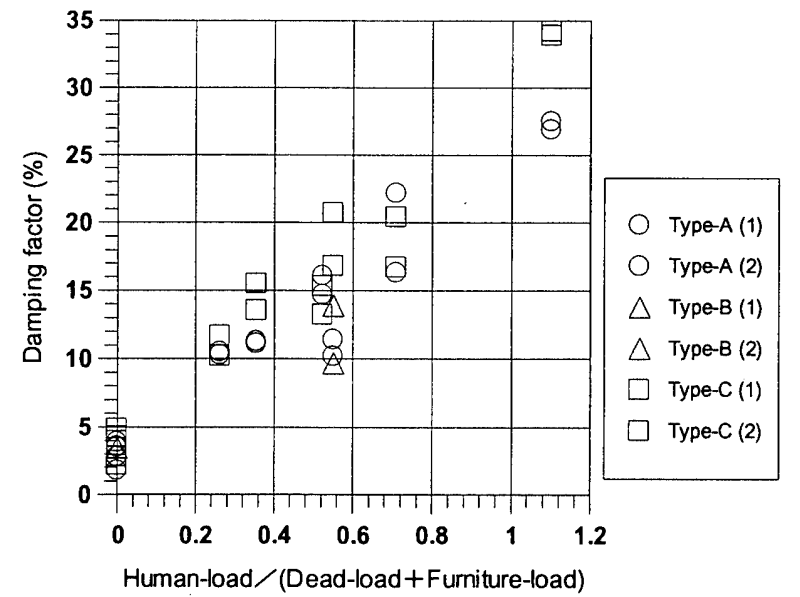

Fig. 8 Relation between damping factor and weight ratio of human-load

4.3 連続体の曲げ振動理論による 1 次固有振動数の推定

床の 1 次固有振動数推定方法としての連続体の曲げ振動理論の適 用性について検討する.

（1）連続体の曲げ振動理論の適用方法

Type-A，Type-B, Type-Cの各試験体について Fig. 9 に示すような 支持条件の連続体としてモデル化し，静的試験より得られた床組の 曲げ剛性（EI）および実測した固定荷重と積載荷重を用いて，連続 体の曲げ振動理論（Appendix [1] 式参照）に基づき 1 次固有振動数 の推定を行うこととする. Type-C の 1 次固有振動数は, 両端ピン支 持梁として捉えて連続体の曲げ振動理論を適用すれば Appendix 中 の [2] 式で求めることができる. Type-A の場合は, 支持点より跳ね 出した部分の曲げ剛性と質量を考慮すれば, Appendix 中の [3] 式を 満足する最小の $\mathrm{f}$ の值（ $\mathrm{f}>0$ ) が 1 次固有振動数となり, 逐次近似 法を用いて同式の解が求められる. Type-B の場合は外的不静定構造 物であり，支点の状態を適切に評価することが必要となる．この場 合，スパン $6.5 \mathrm{~m}$ 位置での支持条件はピン支持とし，跳ね出し部分先 端の拘束状態をバネ要素によりモデル化することとしたが，跳ね出 し部端部支点のバネ定数はスパン中央部集中荷重（静的）試験の荷 重〜スパン中央部変位関係を用いて決定した。具体的には，汎用の 有限要素法解析ソフトを用い, 静的試験によるスパン中央部変位と 解析値とが等しくなるバネ剛性の值を試行錯誤的に求め, バネ定数 を $11.0 \mathrm{kN} / \mathrm{mm}$ と算定した. その状態の固有振動数は, 解析ソフトの 固有值解析により求めることとした.

(2) 計算結果と実験結果の比較

Fig. 10(a) 〜 (c) は, 各試験体条件について, 実験から得られた変 位応答波形に基づく 1 次固有振動数と連続体の曲げ振動理論から得 られた值とをプロットしたものである. 図中の [O] 記号は重量と して［固定荷重＋物品荷重十人間荷重］の值を用いた場合，［口］記 号は重量として人間荷重を除いた [固定荷重十物品荷重] の値を用 いた場合である。 また, 同図中の直線は, 実験值と解析值が一致す

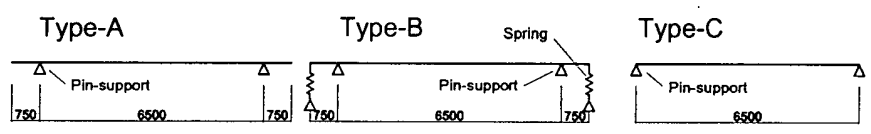

Fig. 9 Schematic diagram of floor models for analyses 


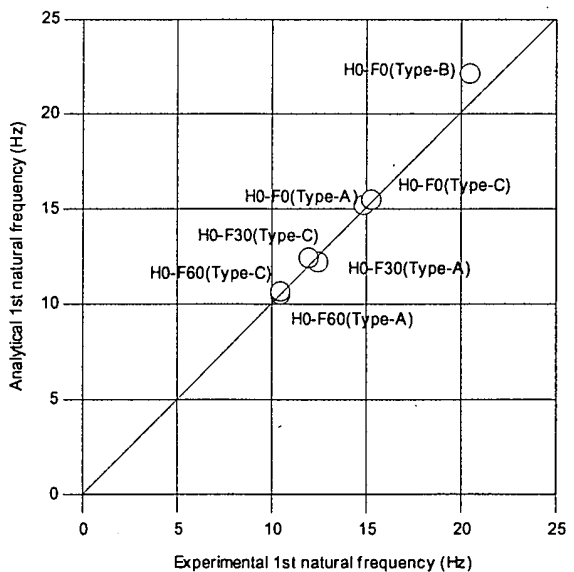

(a) Non-human-load

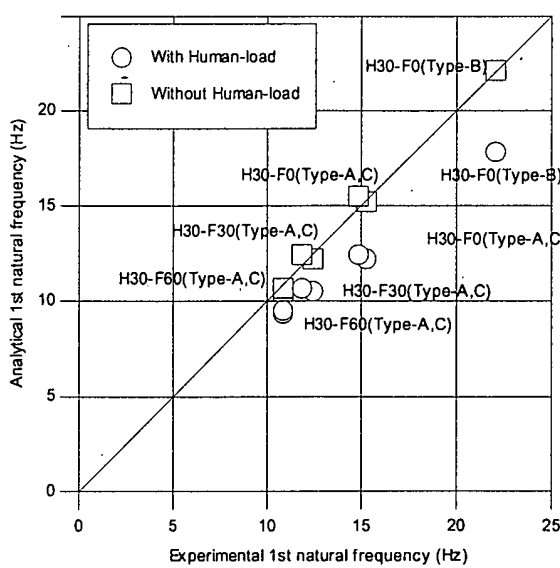

(b) $30 \mathrm{~kg} / \mathrm{m}^{2}$-human-load

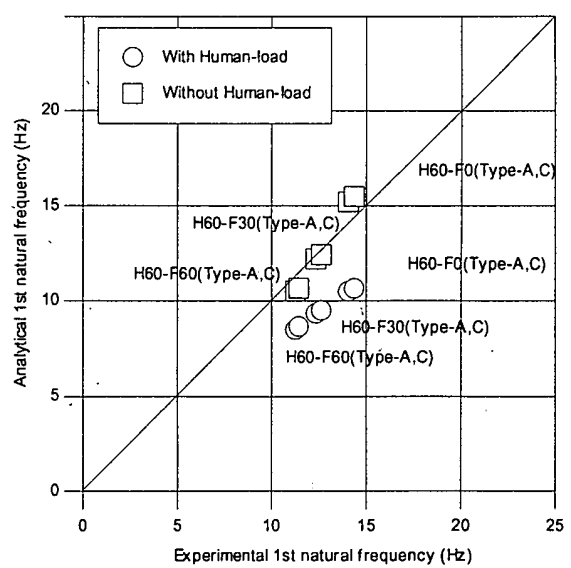

(c) $60 \mathrm{~kg} / \mathrm{m}^{2}$-human-load

Fig. 10 Comparison of first natural frequency between experiments and analyses

る状態を示すものである. Fig. 10 から次のことがいえよう.

人間荷重のない場合 [Fig.10 (a) 参照], 全ての試験体において曲 げ振動理論により推定した 1 次固有振動数の值は実験值とよく一致 しており，連続体の曲げ振動理論の適合性を証している．次に，人 間荷重が $30 \mathrm{~kg} / \mathrm{m}^{2}$ および $60 \mathrm{~kg} / \mathrm{m}^{2}$ の場合 [Fig.11 (b)，(c) 参照] についてみれば, 重量として人間荷重を除いた [固定荷重十物品荷重］ の值を用いて算定される固有振動数（[口]記号）は，実験值と概ね $10 \%$ 以下の誤差範囲で一致していることがわかる.

以上のことから, 床組の 1 次固有振動数は連続体の曲げ振動理論 に基づき算定することが可能であり，その場合，床組の重量として 固定荷重と積載荷重の内の物品荷重だけを考慮すればよいことが確 認されたといえよう．また, Type-Bのような外的不静定構造物につ いても支持状態を適切に評価できれば，連続体の曲げ振動理論を適 用可能であることも確認された.

\section{5.まとめ}

木造床の鉛直振動特性に及ぼす人間荷重等の影響について調べる ために行った，スパン $6.5 \mathrm{~m}$ の実大部分床を対象としたインパクトハ ンマー加振実験により明らかになったことを螕めると以下のように なろう.

（1）床の 1 次固有振動数 $10 \sim 18 \mathrm{~Hz}$ の範囲では，人間荷重の固有振 動数への影響は小さく，人間荷重が載加されても固有振動数はほと んど変化しない.

（2） 1 次固有振動数に対する减衰定数の值は，床の重量（固定荷重 と物品荷重との和）に対する人間荷重の割合に比例して増加する傾 向がある。

（3）木造床の 1 次固有振動数は，曲げ剛性・支持条件・重量（固定 荷重と物品荷重の和）に基づき，連続体の曲げ振動理論を適用して 推定が可能であることが確認された

謝辞 本研究を始めるにあたり，法政大学教授・工学博士 後藤剛史 先生には，環境振動に関して多大なる御教示を戴きました。ここに 記して感謝の意を表します．また，本研究の実験実施に際し，当時 両研究室に在籍した, 職業能力開発総合大学校 山内智香君, 並びに, 明治大学 鎌田俊也君のご協力を得ましたことにお礼申し上げます。

\section{参考文献}

1）日本建築学会: 木質構造設計規準・同解説 - 許容応力度・許容耐力設計法 -, 2002 年 10 月

.2）竹山謙三郎・久田俊彦：木造㦿組の振動障碍に就いて：建築学会論文集第 33 号，昭和 19 年 4 月

3）飯塚五郎蔵：住宅デザインと木構造，丸善，昭和 57 年 4 月

4）日本建築学会 : 建築物の振動に関する居住性能評価指針・同解説，1991.4 5）中村昇・野地清美・西山豊・伊野部健吉・安藤直人：木造床の振動性状と感 覚評価，日本木材学会木材学会誌，Vol. 49, No. 2, p. p. 78-83，2003 6）横山裕: 苦情発生の有無からみた実大住宅床振動の測定条件，境界值の提示, 日本建築学会構造系論文集，第 546 号, p. p. 17-24，2001.8

7）日本建築学会：建築物の振動に関する居住性能評価指針・同解説，2004.5 8）藤野栄一・鈴木秀三・野口弘行：木造㦿の振動特性に及ぼす人間荷重の影響, 日本建築学会大会学術講演梗概集（東海） C-1 構造III, p. p. 241-242，2003.9 9）跉木秀三・野口弘行・藤野栄一・五十田博：木造複合建筑構造技術の開発， 、質ハイブリッド床の鉛直振動特性に関する実験的研究, 日本建築学会大会学 術講演梗概集（東海）C-1 構造 III, p. p. 253-254，2003.9

10）日本建築学会: 建築物荷重規淮案 - 同解説（1975 年制定），昭和 50 年 3 月

11）竹山謙三郎：木構造, 丸善，昭和 26 年 3 月

12）日本建築学会：建築物の振動実験，昭和 53 年 12 月

\section{- Appendix -}

Free vibration equation of motion for bending beam

$$
\begin{aligned}
& E I \frac{\partial^{4} v}{\partial x^{4}}+w \frac{\partial^{2} v}{\partial t^{2}}=0-[1] \\
& E I: \text { Bending stiffness } \\
& w: \text { Mass density } \\
& v: \text { displacement in virtical direction }
\end{aligned}
$$

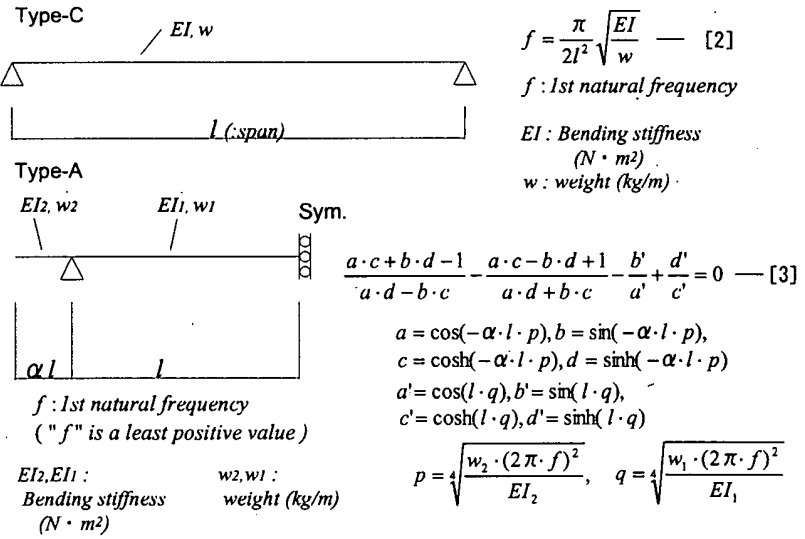

（2004年1月15日原稿受理，2004年 8 月12日採用決定） 